\title{
Effects of Hyperuricemia on Fetal Outcome in Preeclamptic Patients
}

\author{
Mahjabeen $N^{\mathrm{a}}$, Nasreen $\mathrm{SZA}^{\mathrm{b}}$, Begum $\mathrm{F}^{\mathrm{c}}$, Mustary $\mathrm{F}^{\mathrm{d}}$
}

\begin{abstract}
Background: A raised serum uric acid is recognized as an unfavourable fetal outcome of pre-eclampsia. The objective of this study was to determine the relationship between hyperuricemia and fetal outcome in preeclamptic patients.

Methods: This observational study was carried out in the Department of Gynecology and Obstetrics of BIRDEM General Hospital from July 2015 to June 2016. Fifty pre eclamptic pregnant women with hyperuricemia (group A) and 50 preeclamptic pregnant women with normal serum uric acid level (group B) were taken as study subjects. Data were analyzed by SPSS where p value less than 0.05 was considered significant.

Results: Mean age of the patients was $25.88 \pm 4.52$ years and $24.30 \pm 5.09$ years in group A and group B respectively. Mean serum uric acid level was $7.19 \pm 0.62 \mathrm{mg} / \mathrm{dl}$ in group $A$ and $4.83 \pm 0.73 \mathrm{mg} / \mathrm{dl}$ in group $B$. Maximum (66\%) patients were primigravida in group $A$ and $34 \%$ in group B. In this study, intra-uterine death (IUD) occurred in 4 (8\%) cases in group $A$ and in 1 (2\%) case in group B, intra-uterine growth retardation (IUGR) was 20 (40\%) cases in group A and 4 (8\%) cases in group B, low birth weight was in 38 (76\%) cases in group A and 21(42\%) cases in group B. Occurrence of IUGR and low birth weight was significantly higher in group A than group B. APGAR score was significantly lower in group A (5.10 1.61$)$ than that of group $B$ (6.36 1.32$)$. Neonatal intensive care unit (NICU) referral was more in group A (60\%) than group B (20\%).
\end{abstract}

Conclusion: It can be concluded that hyperuricemia is a predictor of poor fetal outcome in pre-eclamptic women.

Key words: Hyperuricemia, pre-eclampsia, fetal outcome.

(BIRDEM Med J 2019; 9(2): 117-120)

\section{Introduction}

A significant number of maternal and perinatal morbidity and mortality is due to preeclampsia in pregnancy. Pregnancy may induce hypertension in women who are

Author Information

a. Dr. Nusrat Mahjabeen, Assistant Professor, Department of Obstetrics \& Gynecology, Z.H. Sikder Women's Medical College \& Hospital, Dhaka.

b. Prof. Dr. Sk. Zinnat Ara Nasreen, Professor \& Head, Department of Obstetrics \& Gynecology, Z.H.Sikder Women's Medical College \& Hospital, Dhaka.

c. Prof. Dr. Ferdousi Begum, Professor \& Head, Department of Obstetrics \& Gynecology, Ibrahim Medical College \& BIRDEM General hospital, Dhaka.

d. Dr. Faryl Mustary, Associate Consultant, NHN, Rampura, Dhaka.

Address of correspondence: Dr. Nusrat Mahjabeen, Assistant Professor, Department of Obstetrics \& Gynecology, Z.H.Sikder Women's Medical College \& Hospital, Dhaka. Email: nusrat.bonny63@gmail.com

Received: June 3, 2018

Accepted: February 28, 2019 normotensive before pregnancy and may aggravate hypertension in those that are hypertensive before pregnancy. ${ }^{1}$ Different studies show that $10-15 \%$ of maternal death is due to preeclampsia, but there is no community based information regarding preeclampsia and eclampsia in Bangladesh. ${ }^{2,3}$

Eclampsia ranks first among the causes of maternal death that is $47.8 \%$. Hypertensive disorder of pregnancy is still the 2 nd most common cause of maternal mortality, accounting for $15.5 \%$ direct death. Preeclampsia in pregnancy is also responsible for $18 \%$ of fetal and infant mortality and $46 \%$ of infants born small for gestational age. ${ }^{4}$

Early screening for preeclampsia may allow vigilant antenatal surveillance and appropriate timing of fetal delivery in order to avoid serious sequel. Unfortunately, various hemodynamic and biochemical measures have been found to have limited accuracy as screening 
measures for this condition. Elevated uric acid level in maternal blood, presumably due to decreased renal urate excretion, are frequently found in women with preeclampsia. Various studies conducted to find out the relationship between elevated serum uric acid level and pre-eclampsia. ${ }^{5}$ Studies of serum uric acid level in normal and hypertensive pregnancy and its relation with the early diagnosis of preeclampsia, severity of preeclampsia and associated peri-natal outcome have been done in various parts of the world by many workers. $^{6-8}$

A small number of such studies, so far, have been done in this country. So, the present study was undertaken to determine the relationship between hyperuricemia and fetal outcome in pre eclamptic patients.

\section{Methods}

This observational study was carried out in the Department of Gynecology and Obstetrics in BIRDEM Hospital from July 2015 to June 2016 over a period of one year. Fifty pre eclamptic pregnant women of 28 to 40 weeks of gestation with hyperuricemia (group A) and 50 pre eclamptic pregnant women of 28 to 40 weeks of gestation with normal serum uric acid level (group B) were enrolled as study subjects. Patient with known chronic renal disease, gout and patient in labour were excluded from this study.

The purpose and procedure of the study was discussed with the patients. Information about the patient was recorded in the prescribed data collection form after taking informed consent. From each patient $5 \mathrm{cc}$ blood was collected and serum uric acid level was measured by enzymatic calorimetric method. Each patient was monitored after delivery for fetal outcome. The weight of the babies, APGAR score and Neonatal intensive care unit (NICU) referral with cause were noted. Statistical analysis was performed by using SPSS version 12 . Association between categorical variables was analyzed by Chi-squared test and continuous variable by independent sample t-test. For all statistical tests, $p$ value $<0.05$ was considered statistically significant.

\section{Results}

Different variables of the subjects were being analysed and compared. Mean age of the patients was $25.88 \pm$ 4.52 years and $24.30 \pm 5.09$ years in group A and group B respectively (Table I). There was no significant difference between the groups.

\begin{tabular}{|c|c|c|c|}
\hline \multirow{2}{*}{ Age } & \multicolumn{2}{|c|}{ Group } & \multirow{2}{*}{$\begin{array}{c}\mathrm{p} \\
\text { value }\end{array}$} \\
\hline & $\begin{array}{c}\text { Group A } \\
(\mathrm{N}=50) \\
\mathrm{n}(\%)\end{array}$ & $\begin{array}{c}\text { Group B } \\
(\mathrm{N}=50) \\
\mathrm{n}(\%)\end{array}$ & \\
\hline$<20$ & $6(12.0)$ & $8(16.0)$ & \\
\hline $20-24$ & $14(28.0)$ & $20(40.0)$ & \\
\hline $25-29$ & $19(38.0)$ & $14(28.0)$ & $0.104 *$ \\
\hline$\geq 30$ & $11(22.0)$ & $8(16.0)$ & \\
\hline
\end{tabular}

Mean serum uric acid level was $7.19 \pm 0.62 \mathrm{mg} / \mathrm{dl}$ in group A and $4.83 \pm 0.73 \mathrm{mg} / \mathrm{dl}$ in group B. Serum uric acid level was significantly higher in group $\mathrm{A}(\mathrm{P}<0.001)$.

Maximum (66\%) patients were primigravida in group A and $34 \%$ in group B (Table II). Chi-square test was done to measure the level of significance. Primigravida was significantly higher in group A than group B. Majority of patients in both groups $(66 \%$ in group A vs $34 \%$ in group) were primigravida (Table II).

Table II Distribution of study population by gravida $(\mathrm{N}=100)$

\begin{tabular}{lccc} 
Gravida & \multicolumn{2}{c}{ Group } & $\mathrm{p}$ \\
\cline { 2 - 3 } & $\begin{array}{c}\text { Group A } \\
(\mathrm{N}=50)\end{array}$ & $\begin{array}{c}\text { Group B } \\
\text { value }\end{array}$ \\
& $\mathrm{n}(\%)$ & $\mathrm{n}=50)$ & \\
\hline $1^{\text {st }}$ & $33(66.0)$ & $17(34.0)$ & 0.017 \\
$2^{\text {nd }}$ & $7(14.0)$ & $14(28.0)$ & \\
$3^{\text {rd }}$ & $8(16.0)$ & $15(30.0)$ & \\
$4^{\text {th }}$ or more & $2(4.0)$ & $4(8.0)$ & \\
\hline
\end{tabular}

In this study, intra-uterine death (IUD) occurred in 4 $(8 \%)$ cases in group A and in $1(2 \%)$ case in group B, intra-uterine growth retardation (IUGR) was 20 (40\%) cases in group A and 4 (8\%) cases in group B, low birth weight was in $38(76 \%)$ cases in group A and 21(42\%) cases in group B. Occurrence of IUGR and low birth weight was significantly higher in group A than group B (Table III). 
Table III Distribution of study population according to fetal outcome $(\mathrm{N}=100)$

\begin{tabular}{|c|c|c|c|}
\hline \multirow[t]{2}{*}{ Complications } & \multicolumn{2}{|c|}{ Group } & \multirow{2}{*}{$\begin{array}{c}\mathrm{p} \\
\text { value }\end{array}$} \\
\hline & $\begin{array}{c}\text { Group A } \\
(\mathrm{N}=50) \\
\mathrm{n}(\%)\end{array}$ & $\begin{array}{c}\text { Group B } \\
(\mathrm{N}=50) \\
\mathrm{n}(\%)\end{array}$ & \\
\hline IUD & $4(8.0)$ & $1(2.0)$ & 0.169 \\
\hline IUGR & $20(40.0)$ & $4(8.0)$ & $<0.001$ \\
\hline Low birth weight & $38(76.0)$ & $21(42.0)$ & 0.001 \\
\hline
\end{tabular}

*multiple response

Neonatal intensive care unit (NICU) referral was significantly more in group $\mathrm{A}(60 \%)$ than group B $(20 \%)$ due to different indications as IUGR, birth asphyxia and hyperbilirubinemia (Table IV) (P 0.001).

Table IV Pattern of NICU referral $(\mathrm{N}=100)$

\begin{tabular}{lccc} 
Causes & \multicolumn{2}{c}{ Group } & $\mathrm{p}$ \\
\cline { 2 - 3 } & $\begin{array}{c}\text { Group A } \\
(\mathrm{N}=50)\end{array}$ & $\begin{array}{c}\text { Group B } \\
(\mathrm{N}=50)\end{array}$ & value \\
& $\mathrm{n}(\%)$ & $\mathrm{n}(\%)$ & \\
\hline IUGR & $14(46.7)$ & $3(30.0)$ & 0.356 \\
Birth asphyxia & $8(26.7)$ & $0(0.0)$ & 0.065 \\
Hyperbilirubinemia & $3(10.0)$ & $0(0.0)$ & 0.298 \\
\hline
\end{tabular}

APGAR score was also significantly lower in group A (5.10 \pm 1.61$)$ than that of group B $(6.36 \pm 1.32)$ which has been showed in Table V.

Table V Comparison of APGAR score between groups $(\mathrm{N}=100)$

\begin{tabular}{lccc} 
APGAR & \multicolumn{2}{c}{ Group } & $\mathrm{p}$ \\
& $\begin{array}{c}\text { Group A } \\
(\mathrm{N}=50)\end{array}$ & $\begin{array}{c}\text { Group B } \\
(\mathrm{N}=50)\end{array}$ & value \\
& $\mathrm{n}(\%)$ & $\mathrm{n}(\%)$ & \\
\hline$<6.0$ & $32(64.0)$ & $11(22.0)$ & \\
$\geq 6.0$ & $18(36.0)$ & $39(78.0)$ & \\
\hline
\end{tabular}

\section{Discussion}

In this study the mean age between two groups of patients were almost similar to two different studies. ${ }^{9,10}$

Regarding gravida, most of the patients were primigravida in group A. Maximum (66\%) patients were primigravida in group A and 34\% in group B. The study reveals incidence of preeclampsia was high in primigravid. Similar conclusion was drawn by Odegard et al. ${ }^{11}$ and Sultana et al. ${ }^{9}$ where they showed nulliparity as a risk factor for preeclampsia.

In this study, IUD was 4(8.0) cases in group A and 1 (2.0) case in group B, IUGR was 20 (40.0) cases in group A and 4 (8.0) cases in group B, low birth weight was in $38(76.0 \%)$ cases in group A and 21(42.0\%) cases in group B. Incidence of IUGR and low birth weight was significantly higher in group A than group B. Hussain et al. ${ }^{10}$ found 2 (8.0\%) IUD and $18(72.0 \%)$ low birth weight in preeclamptic with hyperuricemia patients.

In this study, APGAR score was significantly lower in group A (5.10 \pm 1.61$)$ than that of group B $(6.36 \pm 1.32)$.

IUGR and low birth weight were found significantly higher among pre eclamptic patients with increased serum uric acid level compare to normal serum uric acid level. Though IUD was found higher among pre eclamptic patients with increased serum uric acid level compare to normal serum uric acid level but the difference was not statistically significant. Khaleeq et al. ${ }^{12}$ (2015) found mean uric acid level in pre-eclamptic normouricemic was $3.64 \pm 0.73 \mathrm{mg} / \mathrm{dl}$ and in preeclamptic hyperuricemic was $7.98 \pm 0.85 \mathrm{mg} / \mathrm{dl}$. Hussain et al. ${ }^{10}$ found $2(8.0 \%)$ stillbirth in preeclamptic hyperuricemic and in their study they observed LBW fetal outcome was $72 \%$ in preeclamptic hyperuricemic subjects whereas in pre-eclamptic normouricemic subjects it was $9.38 \%$, which was very negligible in contrast to hyperuricemic group. D'Anna et al. ${ }^{5}$ and Feig et al. ${ }^{13}$ performed same type of study. They got significant relationship between hyperuricemia and LBW fetus.

\section{Conclusion}

Hyperuricemia is one of the most important observations in preeclamptic pregnancies. Many of the pre eclamptic patients show increase serum uric acid level and fetal outcome also poor in these patients. So, measurement of serum uric acid concentration seems to be a useful test to predict fetal complications in the management of women with preeclampsia.

Conflict of interest: Nothing to declare. 


\section{References}

1. Conde Agudelo A, Belizán JM. Risk factors for pre eclampsia in a large cohort of Latin American and Caribbean women. BJOG: Int J Obst \& Gynae 2000;107(1):75-83.

2. Cotter AM, Martin CM, O'leary JJ, Daly SF. Increased fetal DNA in the maternal circulation in early pregnancy is associated with an increased risk of preeclampsia. Am J Obst \& Gyne 2004;191(2): 515-20.

3. Begum MR, Akhter S, Begum A, Khatun M, Quadir E, Choudhury SB. Conservative management of eclampsia and severe pre-eclampsia-A Bangladesh experience. Medscape Women's Health. 2002;7(1):1-1.

4. Subtil D, Goeusse P, Puech F, Lequien P, Biausque S, Breart G. et al. Aspirin (100 mg) used for prevention of pre eclampsia in nulliparous women: the Essai Régional Aspirine MèreEnfant study (Part 1). BJOG: Int J Obst \& Gynae 2003;110(5): 475-84.

5. D’Anna R, Baviera G, Scilipoti A, Leonardi I, Leo R. The clinical utility of serum uric acid measurements in preeclampsia and transient hypertension in pregnancy. Panminerva Medica 2000;42(2):101-3.

6. Stamilio DM, Sehdev HM, Morgan MA, Propert K, Macones GA. Can antenatal clinical and biochemical markers predict the development of severe preeclampsia? Am J Obst \& Gyne 2000;182(3):589-94.
7. Dekker G, Sibai B. Primary, secondary, and tertiary prevention of pre-eclampsia. The Lancet 2001;357(9251):209-15.

8. Nilsson E, Salonen Ros H, Cnattingius S, Lichtenstein P. The importance of genetic and environmental effects for pre eclampsia and gestational hypertension: a family study. BJOG: Int J Obst \& Gynae 2004;111(3):200-6.

9. Sultana R, Ahmed S, Sultana N, Karim SF, Atia F. Association of Serum Uric Acid with Preeclampsia: A Case Control Study. Delta Med Coll J 2013; 1(2): 46-50.

10. Hussain SS, Choudhury MB, Akhter J, Begum S, Mowsumi FR, Azad MK. Fetal Outcome of Pre-eclamptic Mothers with Hyperuricemia. J Dhaka National Med Coll Hos 2012;17(1): 41-43.

11. Ødegård RA, Vatten LJ, Nilsen ST, Salvesen KÅ, Austgulen R. Risk factors and clinical manifestations of pre eclampsia. BJOG: Int J Obst \& Gynae 2000;107(11):1410-16.

12. Khaleeq A. Hyperuricemia as a Predictor of Poor Fetal Outcome in Pre-Eclamptic Women. J Rawalpindi Med Coll 2015; 19(2):171-73.

13. Feig DI, Nakagawa T, Karumanchi SA, Oliver WJ, Kang DH, Finch J, et al. Hypothesis: uric acid, nephron number, and the pathogenesis of essential hypertension. Kidney International. 2004; 66(1):281-87. 